UDC 004.4

DOI: $10.25140 / 2411-5363-2020-4(22)-184-189$

\title{
Lubica Miková
}

\section{CONTROLLER DESIGN FOR DC MOTOR}

Urgency of the research. DC motors are very important and therefore great attention is paid to their development and production. DC motors are used wherever a wide range of speed control is required, or where starting conditions are difficult. They are characterized by simple speed controllability and reliability.

Target setting. The article deals with the analysis of a DC motor with a focus on speed control using the design of a PI controller. Matlab / Simulink software is used for simulation.

Actual scientific researches and issues analysis. The PI controller is the most common combined controller because it has an almost universal use. In a closed loop control system, it eliminates permanent control deviation and improves stability. At the beginning of the control, the influence of the proportional term prevails, with increasing time the influence of the integration term prevails.

Uninvestigated parts of general matters defining. Another task will be to verify the proposed PI controller on a real motor.

The research objective. The main aim was to create control of a DC motor using a PI controller. The proposed control system regulates the motor speed with zero control deviation.

The statement of basic materials. It is a type of electric motor powered by direct current. The main advantages include versatility and simplicity.

Conclusions. The aim of the article was to create a mathematical model, which is the main building block for simulations in a computer environment. Based on the available parameters of the selected DC motor, this mathematical model and its functionality were simulated. Subsequently, the PI controller is designed and its simulation with different load characteristics.

Keywords: DC motor; speed; mathematical model; Matlab/Simulink.

Fig.: 12. Table: 1. Reference: 10.

Introduction. Today, we encounter the problem of controlling DC motors in almost every place. We can find them in various household appliances, work tools, also in vehicles or in industry. Each of these sectors has its own requirements for quality and accuracy of control. An important factor in control is to decide between quality, quantity, and area of use. Obviously, the more precise and high-quality control is needed, the higher the implementation costs, but it is also important that an accurate and costly controller is not always available. Most used actuator in mechatronics motion control applications is DC motors. Despite a variety of resources that propose different selections and design of control strategies to control motions in desired fashion, for instant, most control system used are based on convention PID controller [1-7].

Mathematical model of DC motor. It is a type of electric motor powered by direct current. The main advantages include versatility and simplicity. Due to the fact that the speed of a DC motor is directly proportional to the magnitude of the supply voltage, it is possible to achieve almost any speed compared to AC motors, of course with regard to the mechanical properties of the electric motor.

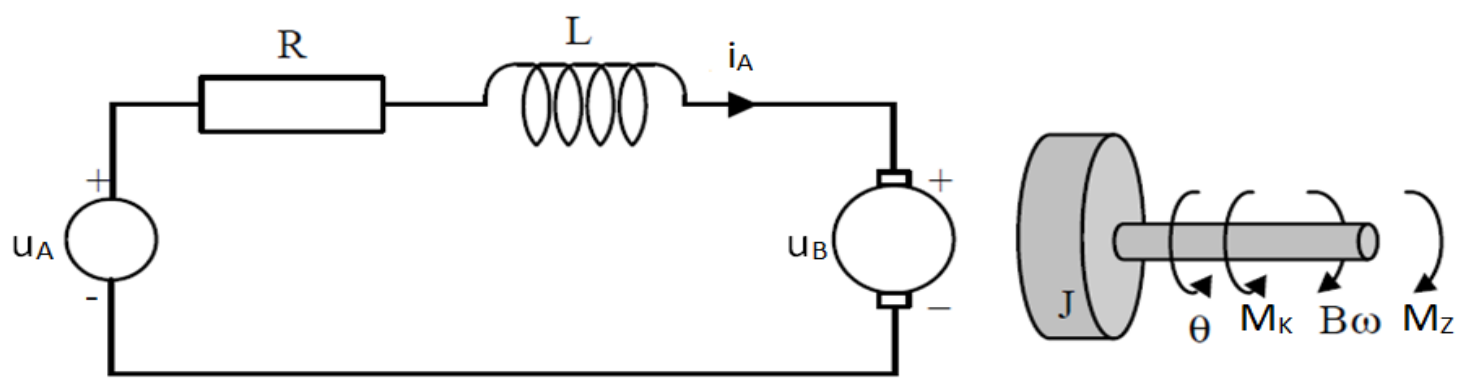

Fig. 1. Model of DC motor

The DC motor model is characterized by the following relationships:

Electrical part of DC motor:

$$
R i_{A}(t)+L \frac{d i_{A}(t)}{d t}=u_{A}(t)-k_{M} \omega(t)
$$

and the transfer function:

$$
\frac{I_{A}(s)}{U_{A}(s)-k_{M} \Omega(s)}=\frac{1}{R+L s} .
$$

(с Любіца Мікова, 2020 
TECHNICAL SCIENCES AND TECHNOLOGIES

Table

Parameters of simulation

\begin{tabular}{|c|c|}
\hline $\boldsymbol{u}_{\boldsymbol{A}}$ & motor armature voltage \\
\hline $\boldsymbol{i}_{\boldsymbol{A}}$ & current \\
\hline $\boldsymbol{u}_{\boldsymbol{B}}$ & feedback voltage \\
\hline $\boldsymbol{R}$ & resistance \\
\hline $\boldsymbol{J}$ & inductance \\
\hline $\boldsymbol{B}$ & moment of inertia of the motor \\
\hline $\boldsymbol{k}_{\boldsymbol{B}}$ & viscous motor and load friction \\
\hline $\boldsymbol{k}_{\boldsymbol{m}}$ & feedback constant \\
\hline $\boldsymbol{M}_{\boldsymbol{Z}}$ & motor constant \\
\hline $\boldsymbol{M}_{\boldsymbol{K}}$ & load moment \\
\hline $\boldsymbol{M}_{\mathrm{T}}$ & motor driving torque \\
\hline
\end{tabular}

Mechanical parts of DC motor and their transfer functions:

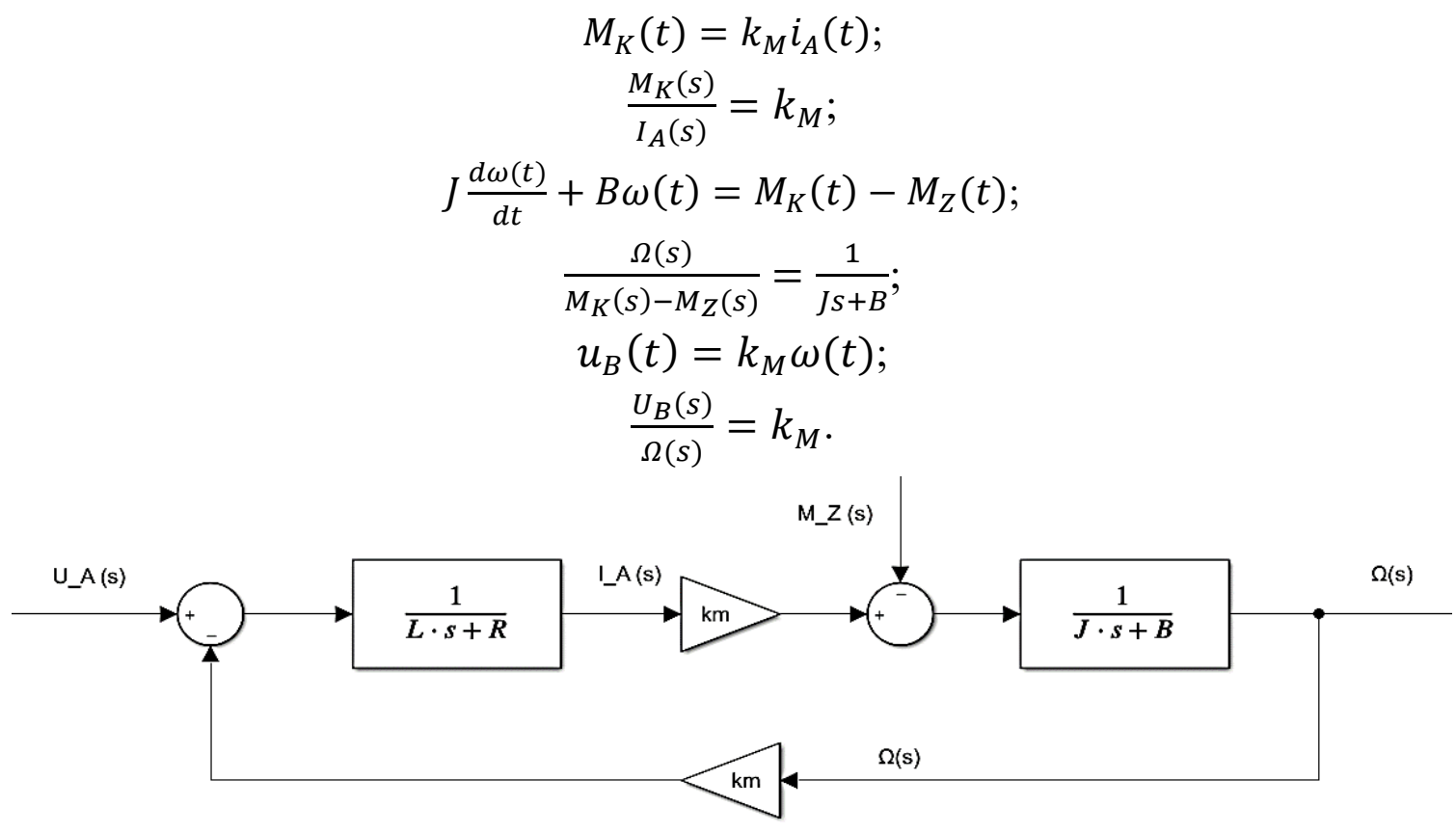

Fig. 2. Mathematical model of DC motor

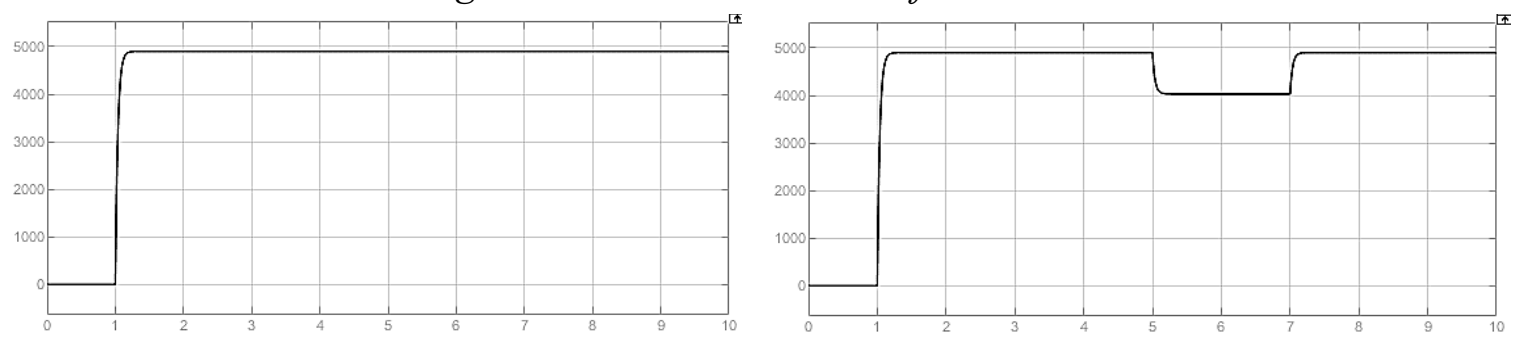

Fig. 3. Speed of DC motor without and with load [rpm]

In Fig. 3 is possible to see the reason for the need to apply the controller. 
PI control of a DC motor. The controller is used mainly in the industrial sector, which contains the Proportional, Integration and Derivative components. It is the task of minimizing the control deviation obtained as the difference between the output value measured by the sensor and the desired value. The P component takes into account current errors, the I component collects past errors, and the $\mathrm{D}$ component predicts future errors based on the rate of change of current errors [8-10]. The transfer function is:

$$
G_{R}(s)=K_{p}+\frac{K_{i}}{s}+K_{d} s=\frac{K_{p} s+K_{i}+K_{d} s^{2}}{s} .
$$

Pole placement method. An assisted pole placement method has been proposed to help the designers in their choice of the design parameters. Once the desired rise time, settling time and percentage of overshoot of the step response of the closed-loop system with respect to a reference change have been specified, the computation of the controller is performed automatically [9]. By suitable positioning of the poles, it is possible to influence the stability or periodicity of the control output [3].

Controller design considers a 3nd order system, characteristic equation has the form:

$$
G_{3 R}(s)=\frac{k \omega_{0}^{2}}{s^{3}+(2 \xi k) \omega_{0} s^{2}+(1+2 \xi k) \omega_{0}^{2} s+k \omega_{0}^{3}} .
$$

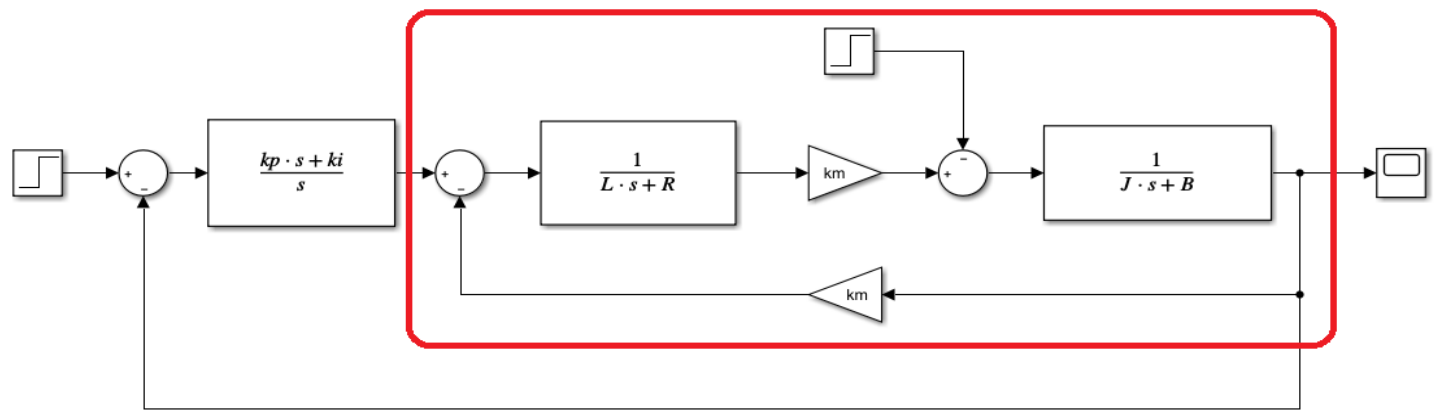

Fig. 4. Closed-loop control system

By simplifying the block scheme, we get the final transfer function of control system:

$$
G(s)=\frac{k m k_{P} s+k m * K_{I}}{L J s^{3}+(L B+R J) s^{2}+\left(R B+k m^{2}+k m k_{P}\right) s+k m k_{I}} .
$$

The PI controller constants are obtained by comparing the coefficients of the characteristic equation of the desired and the final transfer function:

$$
\begin{gathered}
K_{I}=\frac{k \omega_{0}^{3} L J}{k m} ; \\
K_{P}=\frac{(1+2 \xi k) \omega_{0}^{2} L J-R B-k m^{2}}{k m} .
\end{gathered}
$$
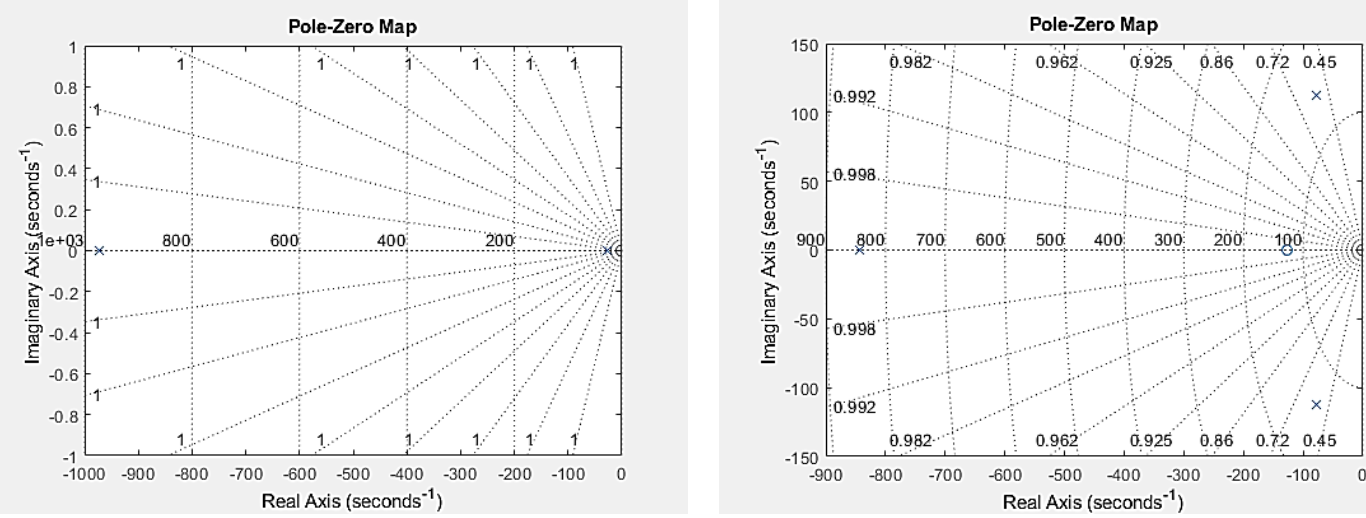

Fig. 5. Pole position uncontrolled and controlled system 
TECHNICAL SCIENCES AND TECHNOLOGIES

Verification of the functionality of the control was simulated under the action of two type disturbance variables.
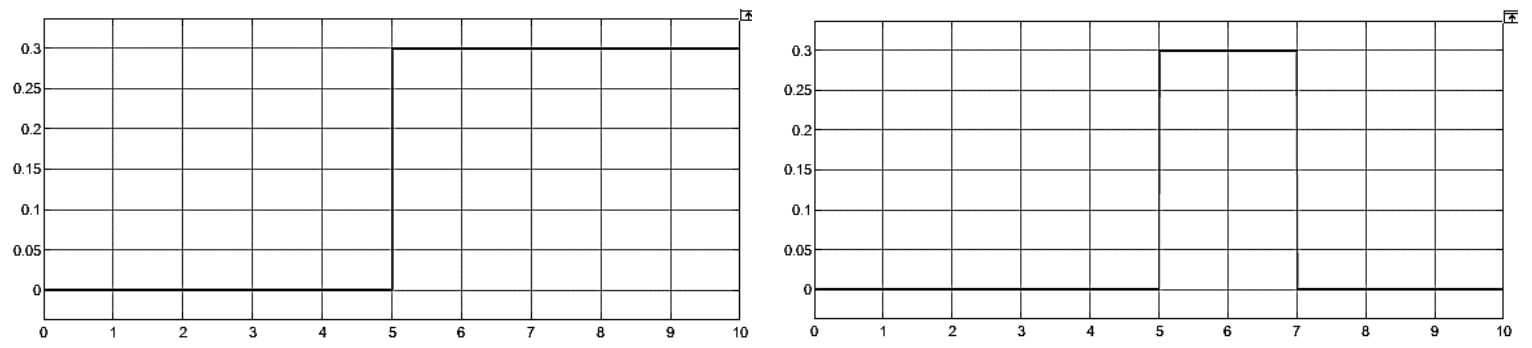

Fig. 6. Disturbance variables (constant and square load)
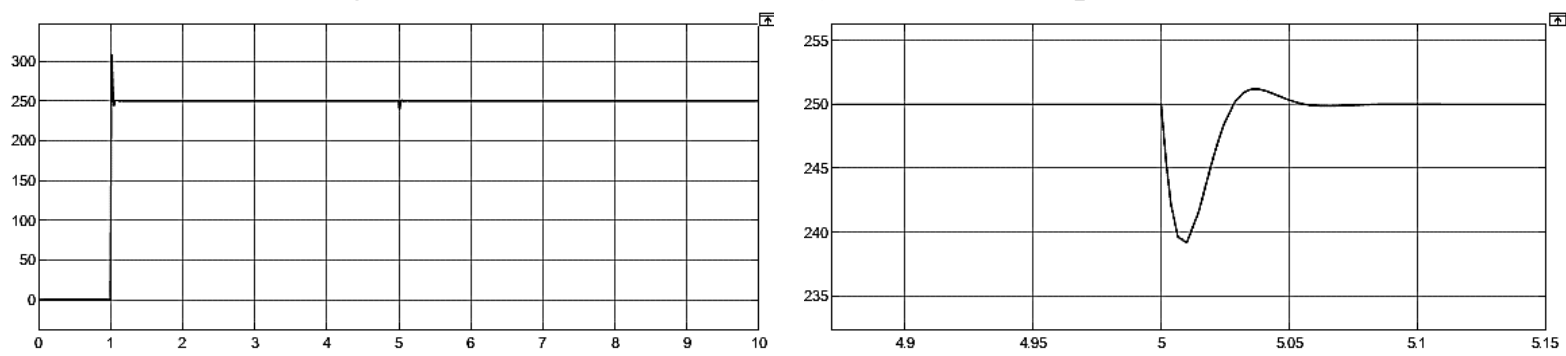

Fig. 7. Speed of DC motor at constant load
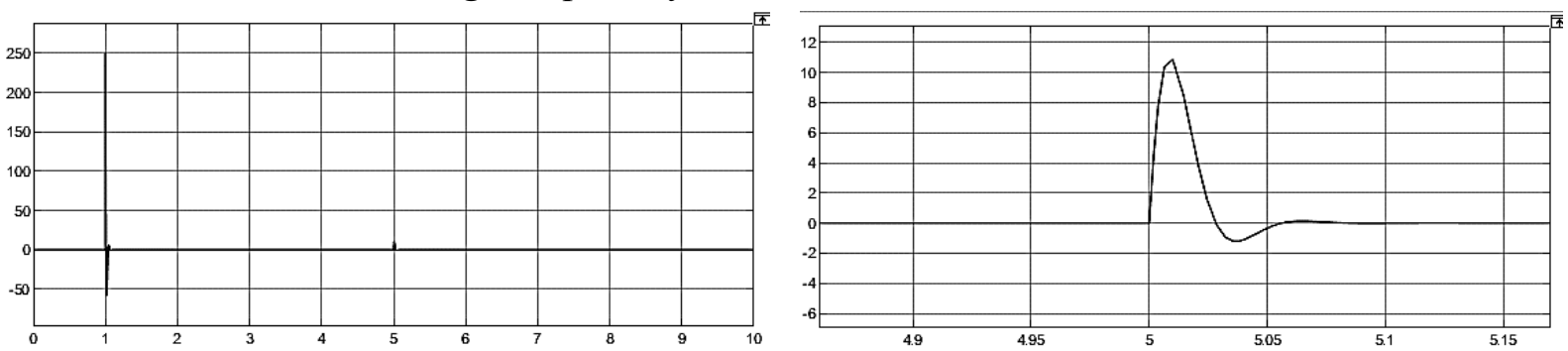

Fig. 8. Control deviation of closed-loop control system at constant load

One of the important factors for the control of the DC motor is the intervention of the action variable in the change of the load, which is on Fig. 9.
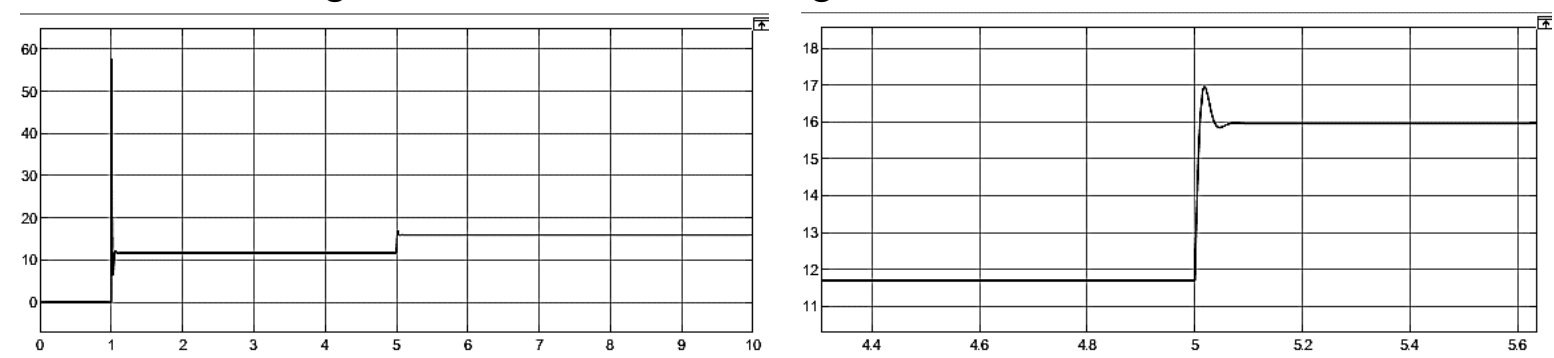

Fig. 9. The course of the action variable at constant load

During a square load, the load is characterized according to Fig. 9. In practice, such a situation may occur when connecting a load using a coupler and then disconnecting it. As in the previous case, it is necessary to monitor the output parameters to verify the correct operation of the close loop control system. 

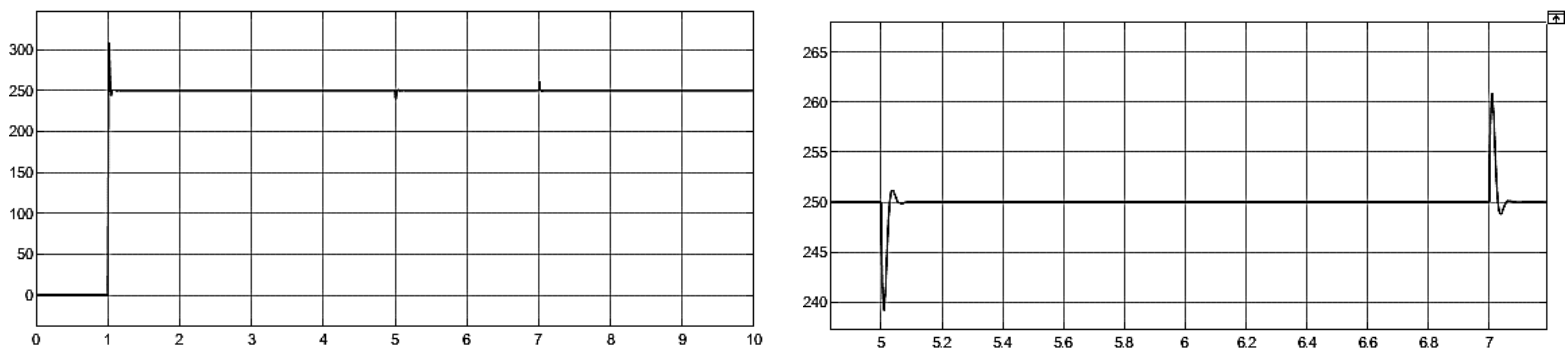

Fig. 10. V Control deviation of closed-loop control system at square load
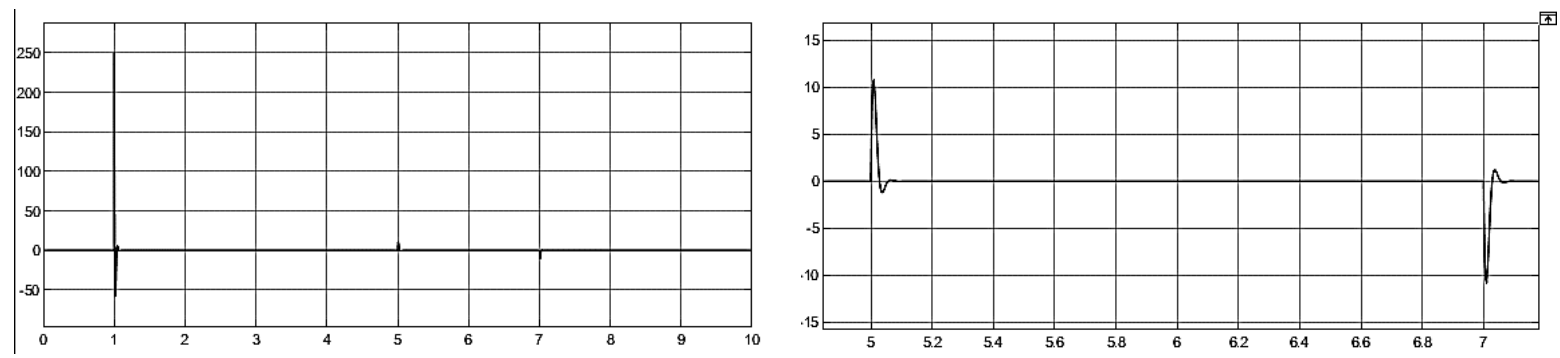

Fig. 11. Control deviation of closed-loop control system at square load
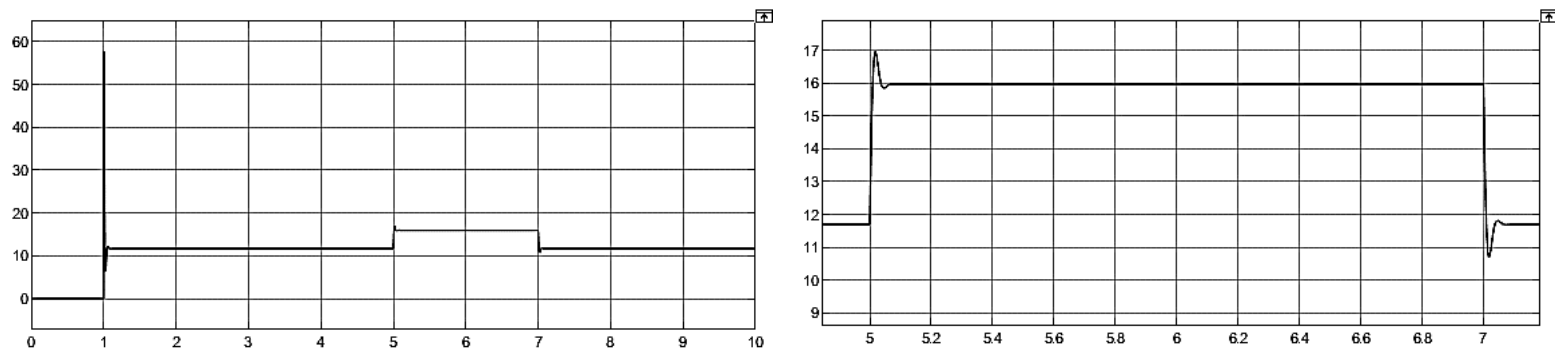

Fig. 12. The course of the action variable at square load

Conclusion. In everyday life, we encounter electric motors of any kind very often and due to the growing tendency to automate all previously manually controlled or controlled activities, it will be even more common in the future, so it is important in technical practice to know the basic components of electric motors and various control options. It was ultimately possible to improve this technology and minimize possible failures during the cycle. The aim of the article was to create a mathematical model, which is the main building block for simulations in a computer environment. Based on the available parameters of the selected DC motor, this mathematical model and its functionality were simulated. Subsequently, the PI controller is designed and its simulation with different load characteristics. From the simulation, the PI controller reacts to changes in load quickly and efficiently, what corresponds to zero control error in steady space.

Acknowledgement. This research was funded by Slovak Grant VEGA 1/0389/18 "Research on cinematically redundant mechanisms".

\section{References}

1. Alotaibi A.M. (2013) Modeling and Motion Control Selection and Design of Electric Motor for Mechatronics Robotics Applications. International journal of control, automation and systems, vol. 1, no 2, ISSN 2165-8277.

2. Jamal A. M. (2011) Modeling, Analysis and Speed Control Design Methods of a DC Motor. Eng. \& Tech. Journal, Vol. 29, No. 1.

3. Miková, L., Virgala, I., Kelemen, M. (2016). Speed control of DC motor. American Journal of Mechanical Engineering. Vol. 4, no. 7 (2016), p. 380-384. - ISSN 2328-4102.

4. Timko, J., Žilková, J., Dudrik, J., Girovsky, P. (2009). Elektrické akčné členy a pohony. Košice FEI TU. 
5. Isermann, R. (1998). Mechatronic systems - Innovative products with embedded control. Control Engineering Practice 16, (pp. 14-29).

6. Jae-Bok, S., Kyung-Seok, B. (19988). Throttle actuator control system for vehicle traction control. Department of Mechanical Engineering, Korea University.

7. Horn, J. (1999). Neural adaptive tracking control of a DC motor. Informat Sci.

8. Farid, M. (2008). PID controller design for controlling DC motor speed using Matlab application. University Malaysia Pahang.

9. Kinnaert, M., Peng, Y., (1995). Digital Control Systems Implementation Techniques. Control and Dynamic Systems.

10. Pavković, D. (2003). Identification and control of electronic throttle drive. Master's thesis, Faculty of Electrical Engineering and Computing, University of Zagreb, Croatia.

УДК 004.4

\section{Любіиа Мікова}

\section{РОЗРОБКА РЕГУЛЯТОРА ДЛЯ ДВИГУНА ПОСТІЙНОГО СТРУМУ}

Актуальність теми дослідження. Двигуни постійного струму (ДПС) є дуже важливими в сучасному світі, тому їх розробиі та виробництву приділяється велика увага. Вони використовуються там, де існує потреба регулювання швидкості в широкому діапазоні або присутні важкі умови запуску. Вони відрізняються простотою керування та високою надійністю.

Постановка проблеми. Стаття присвячена аналізу двигуна постійного струму з акцентом на регулювання швидкості з використанням пропориійно-інтегрального (ПI)-регулятора. Для моделювання використовується програмне забезпечення Matlab/Simulink.

Аналіз останніх досліджень і публікацій. ПІ-регулятор с одним з найбільш поширених комбінованих регуляторів та має універсальне застосування. В системі управління зі зворотним зв'язком він усуває постійне відхилення регулювання і покращує стабільність. Він характеризується тим, щчо в початковий момент збурення переважає вплив пропориійного регулятора, а потім - інтегрального.

Виділення недосліджених частин загальної проблеми. Не до кіния дослідженим є питання розробки ПІрегулятора з урахуванням параметрів реального двигуна.

Постановка завдання. Основною метою було створити систему управління двигуном постійного струму за допомогою ПІ-регулятора. Запропонована система управління регулює швидкість двигуна з нульовим відхиленням по управлінню.

Виклад основного матеріалу. Запропоновано математичну модель, щуо дозволяє проводити моделювання та аналіз системи управління ДПС на основі ПІ-регулятора. Наведено результати моделювання для різних типів збурень в програмному комплексі Matlab/Simulink.

Висновки. Створено математичну модель, яка є основою для моделювання системи управління ДПС на основі ПI-регулятора в комп 'ютерному середовищі Matlab/Simulink. На основі доступних параметрів вибраного двигуна постійного струму було промоделювано роботу системи управління стосовно стабілізації швидкості. В подальшому планується розробка ПI-регулятора та його моделювання з різними характеристиками навантаження.

Ключові слова: двигун постійного струму; ивидкість; математична модель; Matlab/Simulink.

Рис.: 12. Табл.: 1. Бібл.: 10

Miková Lubica - doc. Ing., PhD., Faculty of Mechanical Engineering, Technical University of Kosice (Letna 9, 04200 Kosice, Slovakia).

E-mail: lubica.mikova@tuke.sk

Scopus Author ID:_55259674100

Miková, L'. (2020). Controller design for DC motor. Technical sciences and technologies, 4(22), pp. 183-189. 